Prepared in cooperation with the Metropolitan Water Reclamation District of Greater Chicago and the Chicago Department of Transportation

\title{
Hydrologic Monitoring for Chicago's Sustainable Streetscapes Program
}

The Chicago Department of Transportation's Sustainable Streetscapes Program is an innovative program that strives to convert Chicago's neighborhood commercial areas, riverwalks, and bicycle facilities into active, attractive places for Chicagoans to live, work, and play. The objective of each project is to create flourishing public places while improving the ability of infrastructure to support dense urban living. The U.S. Geological Survey (USGS), in cooperation with the Metropolitan Water Reclamation District of Greater Chicago (MWRDGC), and the Chicago Department of Transportation (CDOT), is monitoring the pre- and postconstruction hydrologic characteristics of an urban corridor on the south side of Chicago (fig. 1) that is being renovated using sustainable streetscapes technology.

The CDOT Sustainable Streetscapes Program utilizes urban stormwater best-management practices (BMPs) to reduce the storm runoff to the local combined sewer system. The urban stormwater BMPs include permeable pavement, bioswales, infiltration basins, and planters (figs. 2, 3, 4). The urban stormwater BMPs are designed to capture the first flush of storm runoff through features that enhance the infiltration of stormwater runoff to shallow groundwater.

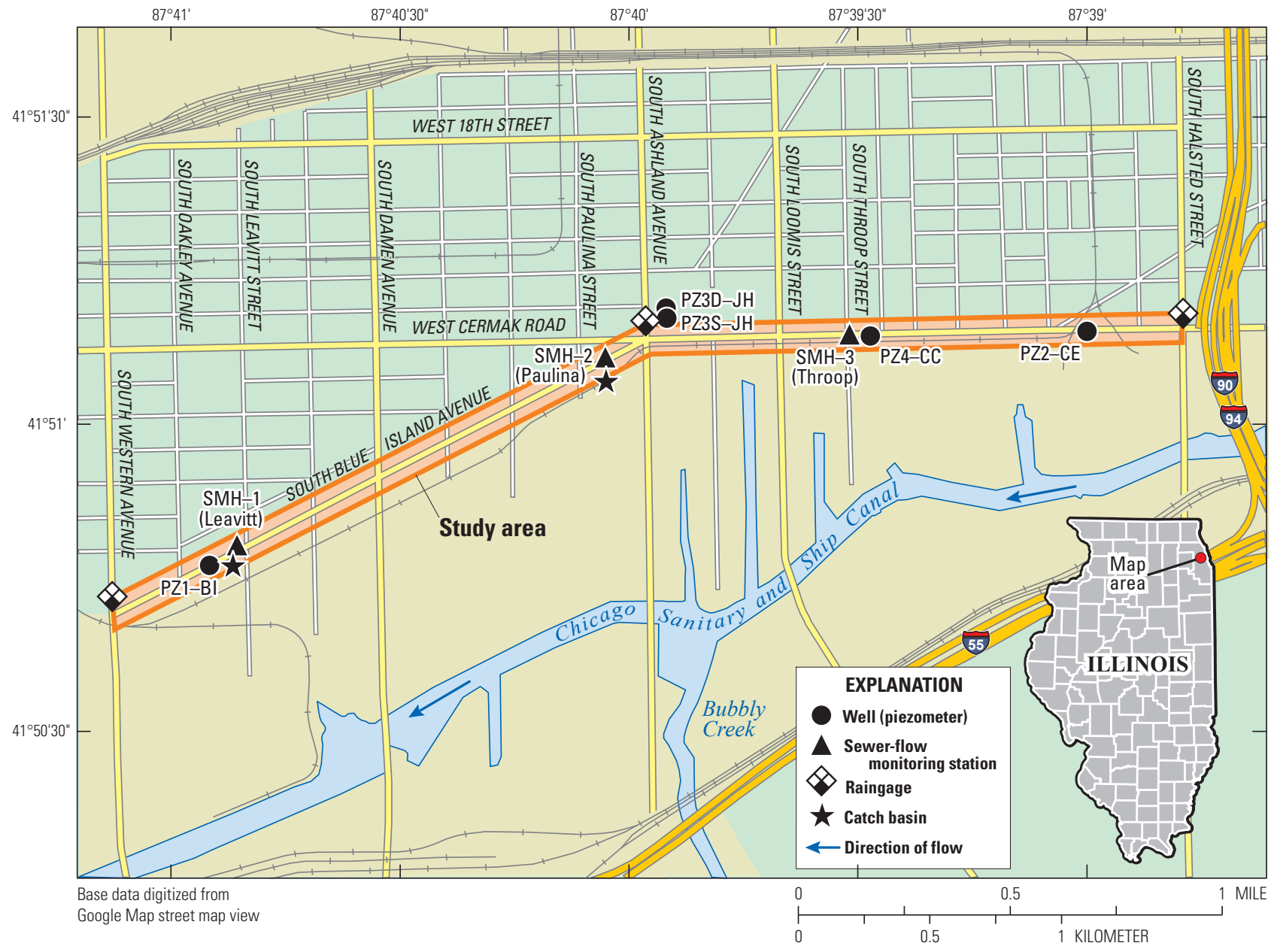

Figure 1. The project study area is a 2-mile reach of West Cermak Road and South Blue Island Avenue between South Halsted Street on the east and South Western Avenue on the west. Preconstruction monitoring began in 2009 and is planned to continue through postconstruction in 2015. 
Figure 2. Chicago Department of Transportation illustration of a typical bioswale layout.
0

White light lamp, full cut off fixture

$40 \%$ more energy efficient
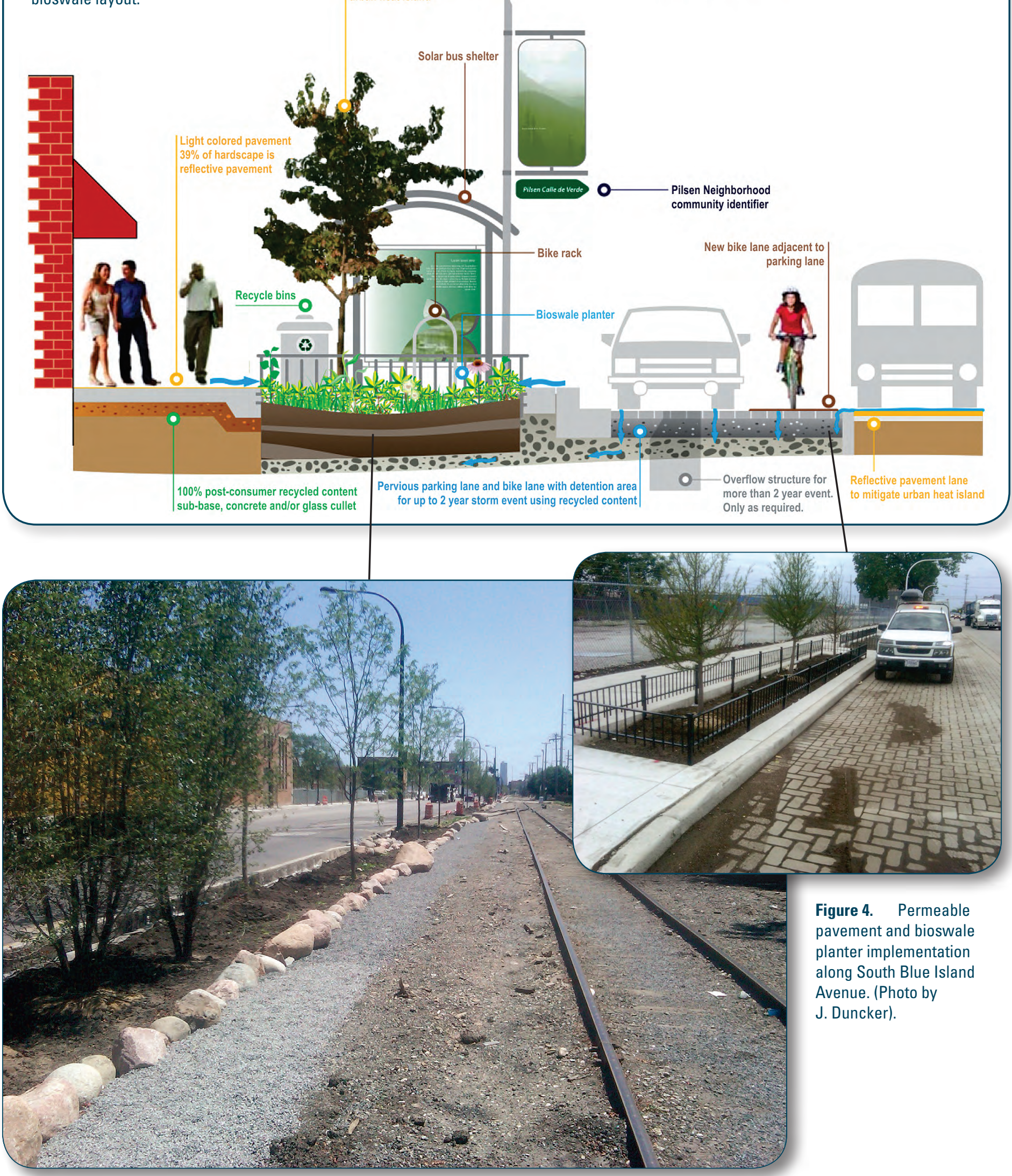
pavement and bioswale planter implementation along South Blue Island Avenue. (Photo by J. Duncker).

Figure 3. Bioswale implementation along West Cermak Road. (Photo by J. Duncker.) 
The hydrology of the Sustainable Streetscapes Program area is being monitored to evaluate the impacts and effectiveness of the urban stormwater BMP's. Continuous monitoring of rainfall, sewer flows, stormwater runoff, soil moisture, and groundwater levels will give engineers and scientists measured data to define baseline pre- and postconstruction conditions for the evaluation of the BMPs (fig. 5).

\section{A. Sewer-flow monitoring station SMH-1}
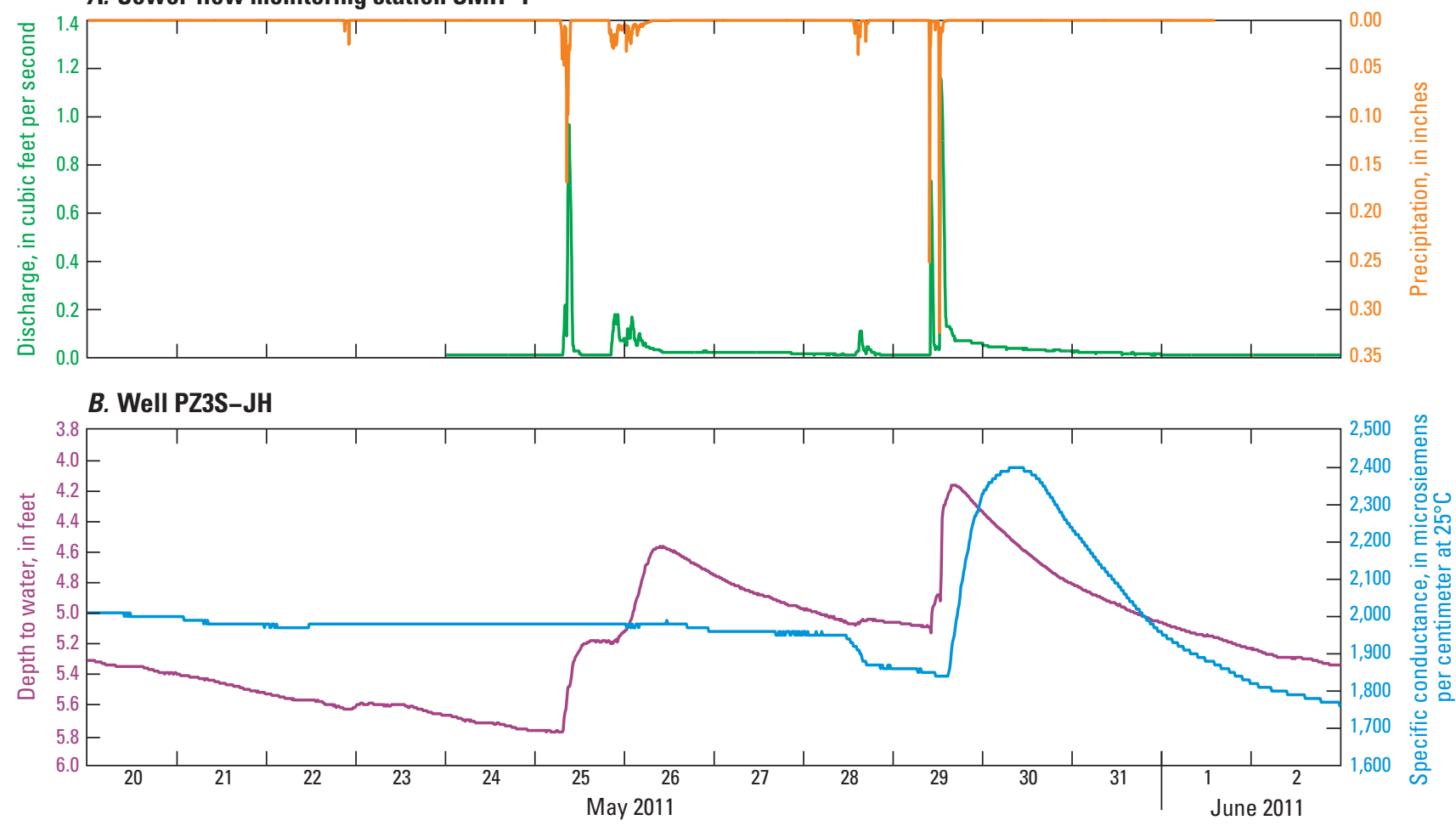

Figure 5. Response from precipitation events on $A$, sewerflow monitoring station SMH-1 and on $B$, groundwater levels and specific conductance at well PZ3S-JH between May 20 and June 2, 2011.

\section{Rainfall}

Three tipping-bucket rain gages are located along the project corridor. The data provide information on the intensity and volume of rainfall. Rainfall can be highly variable even over a small area like the project corridor (fig. 6).

Figure 6. Rainfall and sewer water levels in the Streetscapes Corridor from June through September, 2014. (Photo by J. Duncker.)

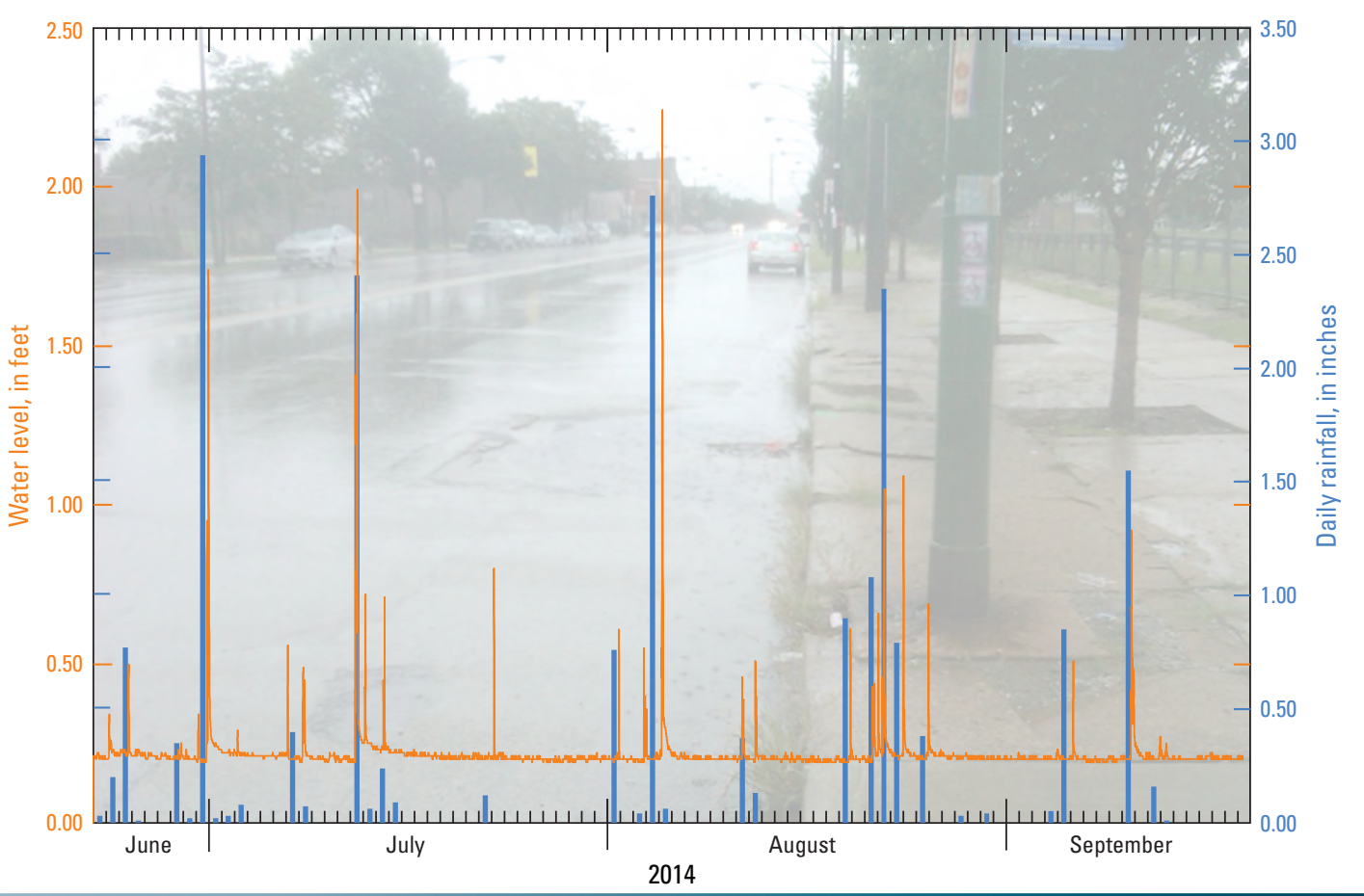




\section{Sewer Flow}

Continuous recording meters are located at specific locations in the combined sewers to record water level and flow during both dry weather (mostly sanitary flow) and wet weather conditions (stormwater runoff in addition to the sanitary flow) (figs. 7 and 8). Sanitary flow is the largest source of flow in the combined sewers during dry weather, and stormwater runoff and sanitary flow combine during wet weather. The sewer flow data allow engineers and scientists to calculate total runoff volume for selected storm events (fig. 9).

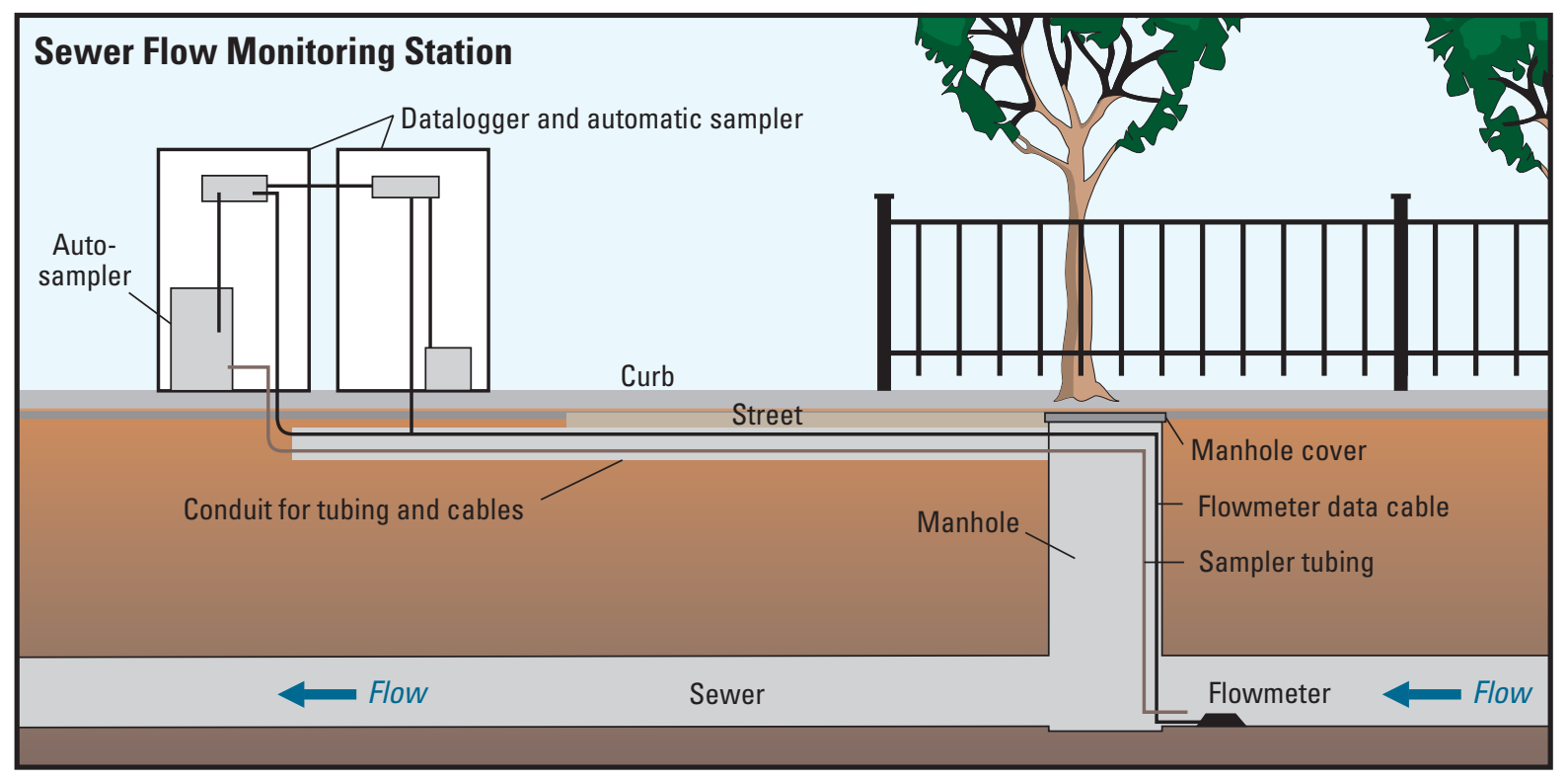

Figure 7. The flowmeter within the sewer is connected to a datalogger and an automatic sampler in huts above ground that automatically withdraw water from the sewer during storm events.

Figure 8. Sewer-flow monitoring station at South Leavitt Street and South Blue Island Avenue prior to installation of stormwater BMPs. (Photo by J. Duncker.)

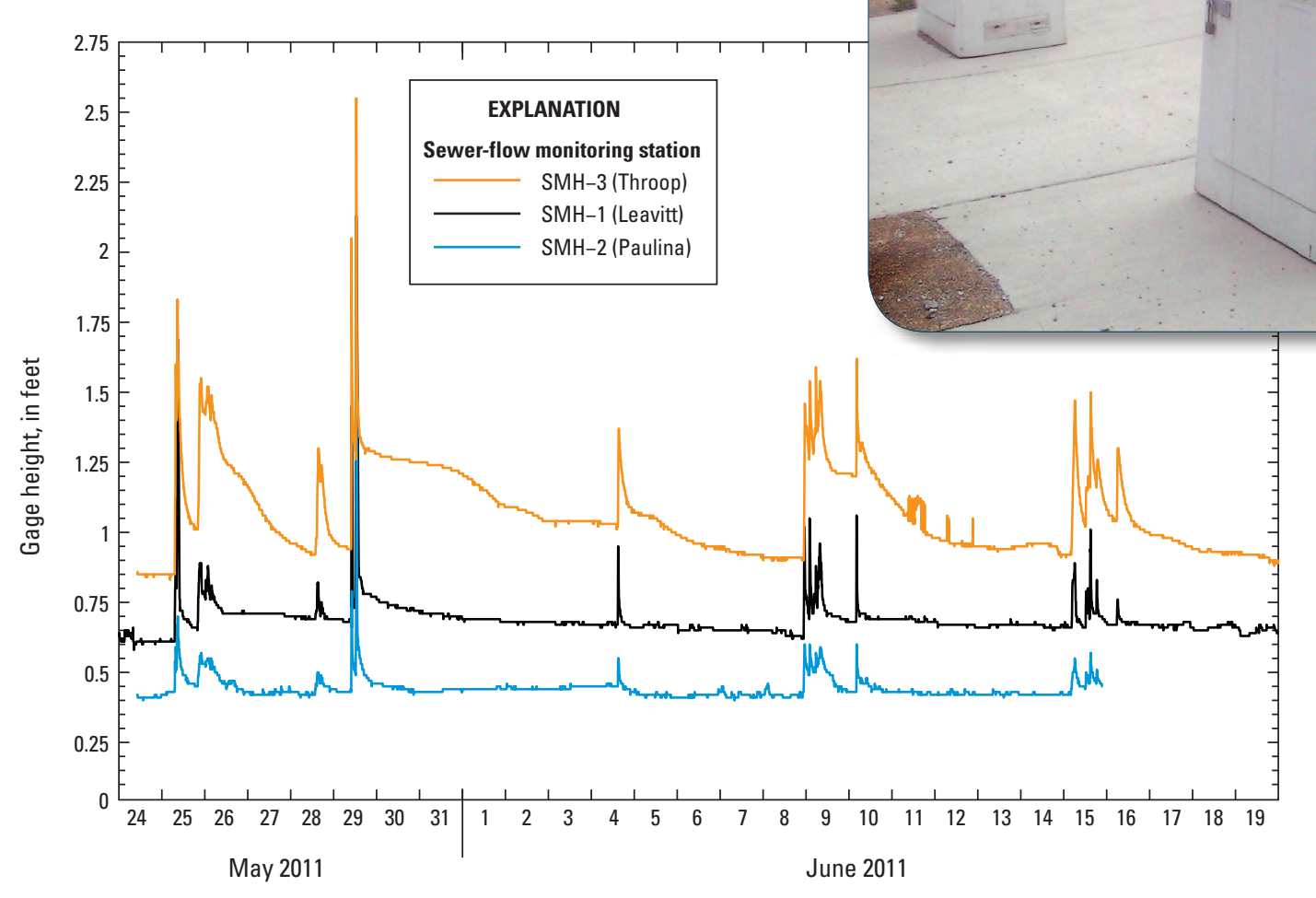

Figure 9. Water level data from the three sewer-flow monitoring locations in the Streetscapes study area. A delayed receding limb of the hydrograph at the Throop Street location is caused by extensive amounts of sediment in the local combined sewer. 
Wells are located within the project corridor to record water levels and help determine the direction of movement of groundwater in response to rainfall and snowmelt (figs. 10-12). In urban settings with aging sewer systems, groundwater can seep into the sewers or combined sewage can seep from the sewers into the local groundwater system. The groundwater data are also important in evaluating the overall impacts of increased infiltration resulting from BMPs.

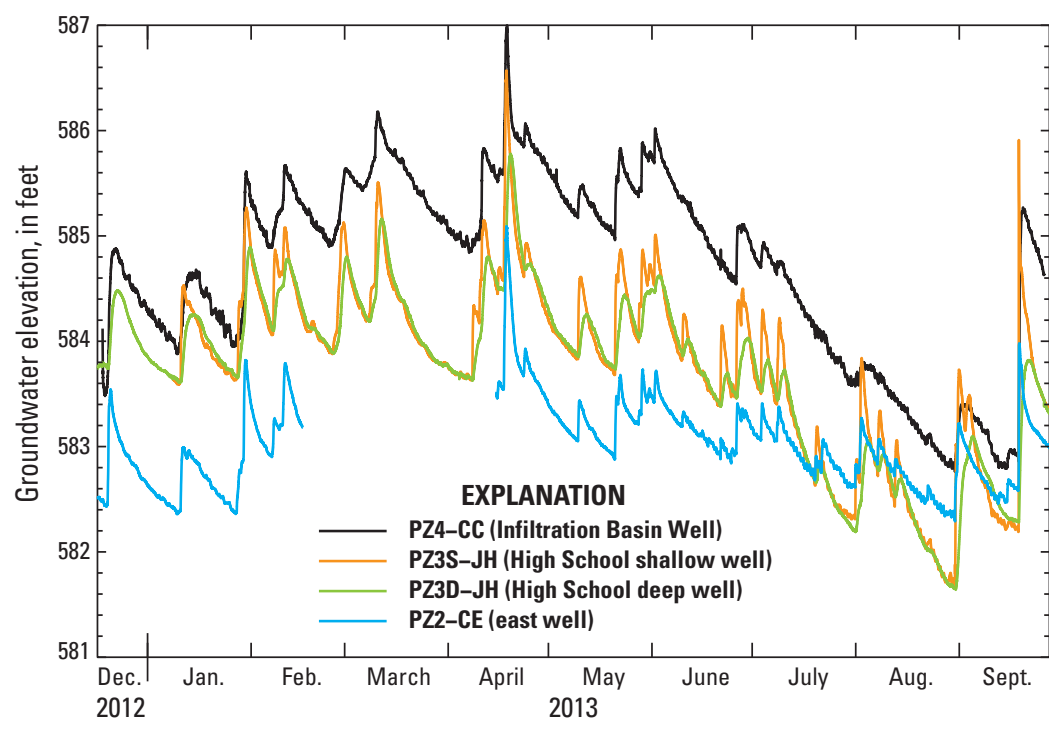

Figure 10. Groundwater level data from the wells in the project corridor for December 2012 through September 2013. Water levels in the area of the bioswale are at a higher elevation in general.

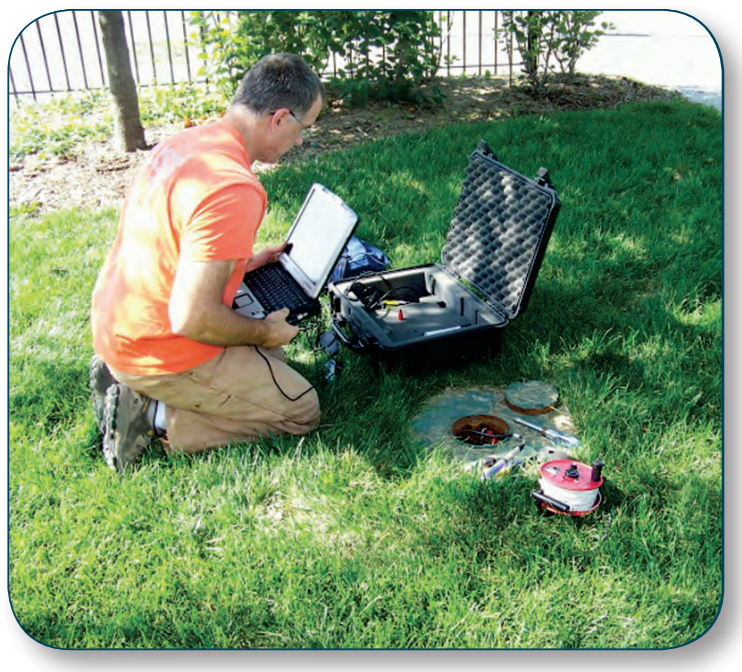

Figure 11. Shallow groundwater levels are continuously monitored using dataloggers. (Photo by J. Duncker.)
Data from wells show the relative water levels of shallow groundwater, water levels in the combined sewer system, and nearby surface-water channels within the project corridor (fig. 12). In some aging urban sewer systems, the local combined sewer system lies below the water table and receives substantial amounts of groundwater inflow, which can significantly reduce the amount of additional water the sewer system can accept.

Figure 12. Water levels in the combined sewers, groundwater wells and Bubbly Creek collected on September 23, 2009.

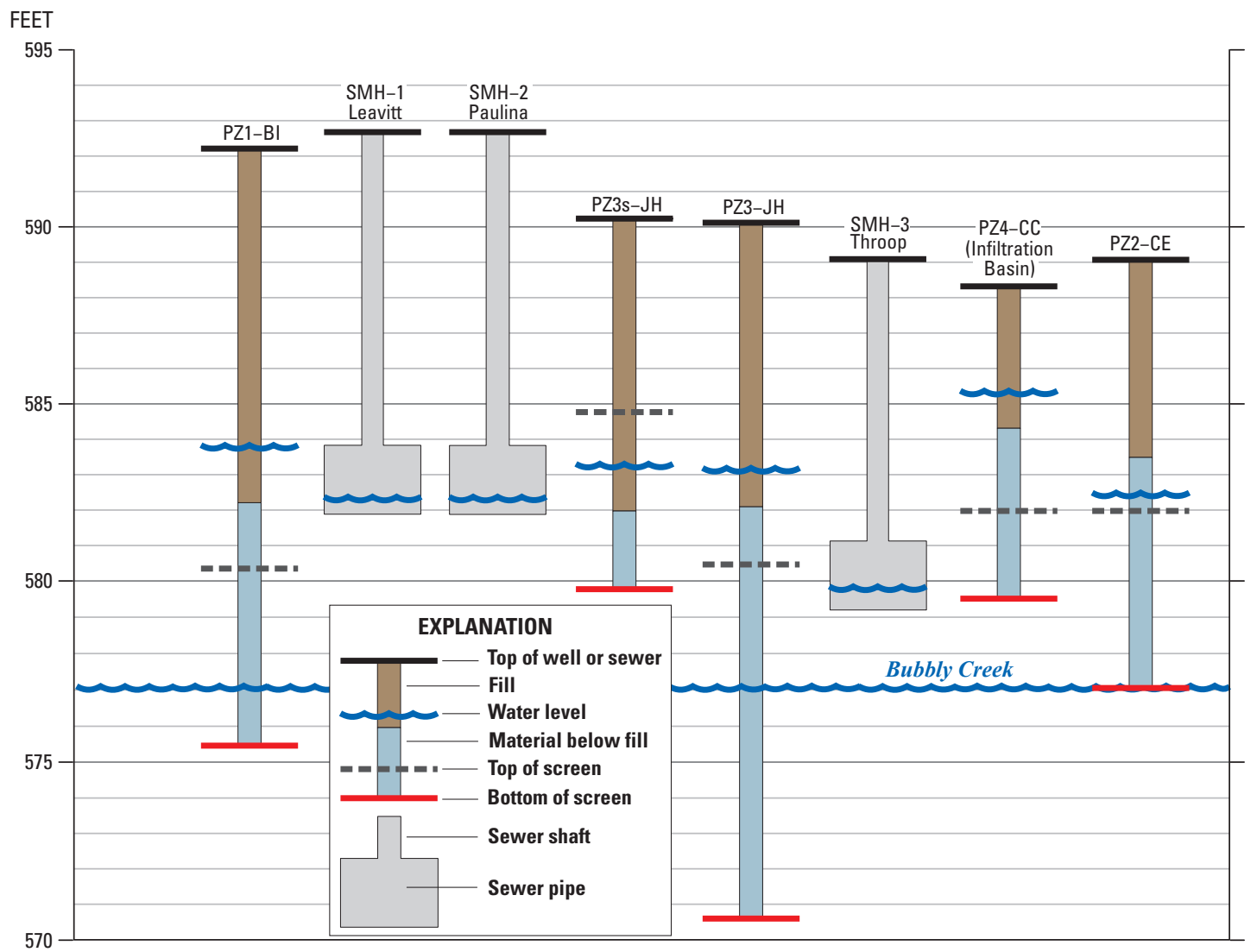




\section{Bioswale}

The bioswale along the south side of West Cermak Road near South Throop Street functions to infiltrate stormwater runoff from the road. Stormwater on the road surface initially drains to the curb and then flows along the curb until it reaches a curb cut-out (fig. 13). Materials within the bioswale allow stormwater to infiltrate and reduce the load to the combined sewer (fig. 14).

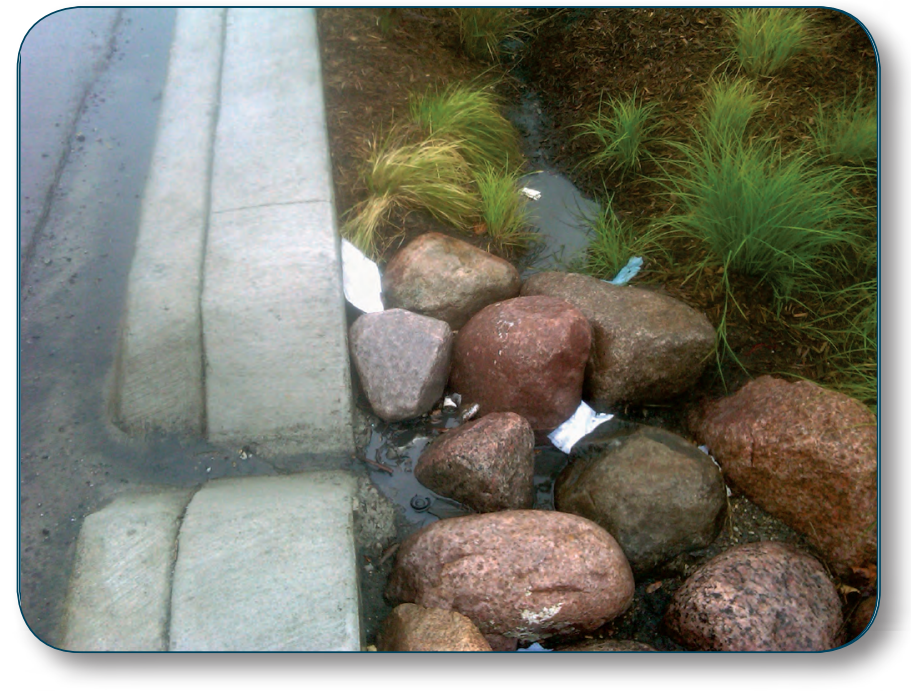

Figure 13. A curb cut-out with storm-water runoff draining into the bioswale along West Cermak Road. (Photo by J. Duncker.)

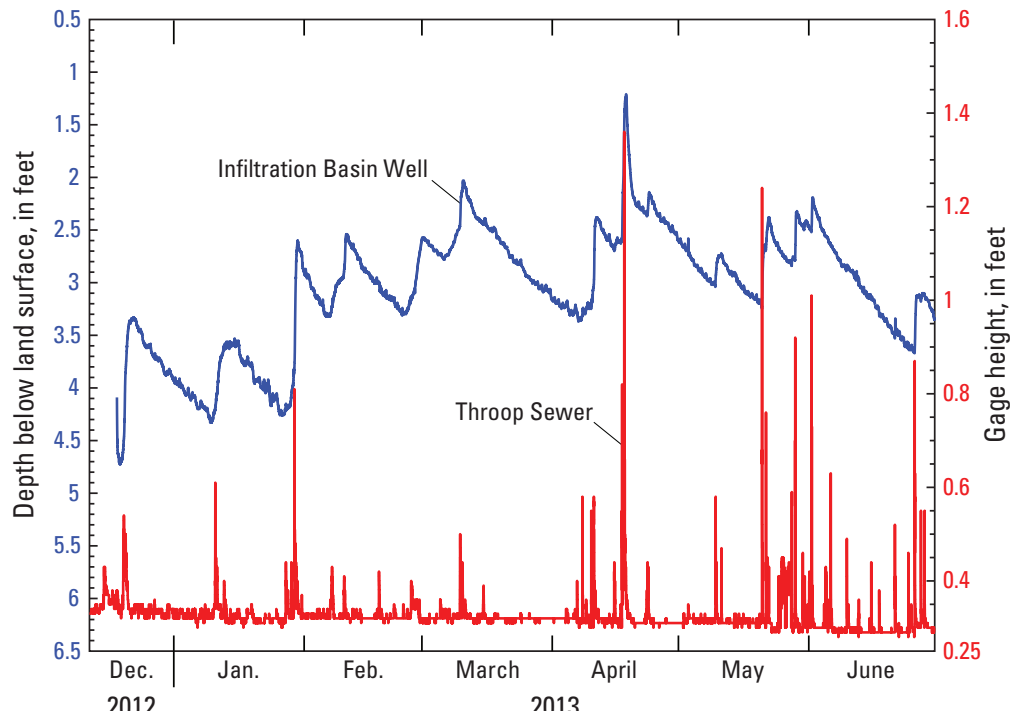

Figure 14. Water level in the well PZ4-CC (blue) and water level in the sewerflow monitoring station SMH-3Throop Street (red). Note that water levels in the combined sewer did not exceed 2.0 feet during the April 18, 2013 storm event when approximately 4 inches of rain fell in the project study area.

\section{Catch Basins}

A common feature in urban areas are curbside catch basins that collect stormwater runoff from paved streets. Stormwater drains first to the curb and then flows along the curb to the catch basin. Lateral sewer pipe connects the catch basin to the combined sewer beneath the street. The use of permeable pavers along the curbs in the project study reach let stormwater infiltrate before it reaches the curb, thus reducing the amount of stormwater draining to the combined sewers (fig. 15).

Water-level data from catch basins in the project study area show the effects of permeable pavers in reducing the stormwater drainage to the combined sewers (figs. 15 and 16).

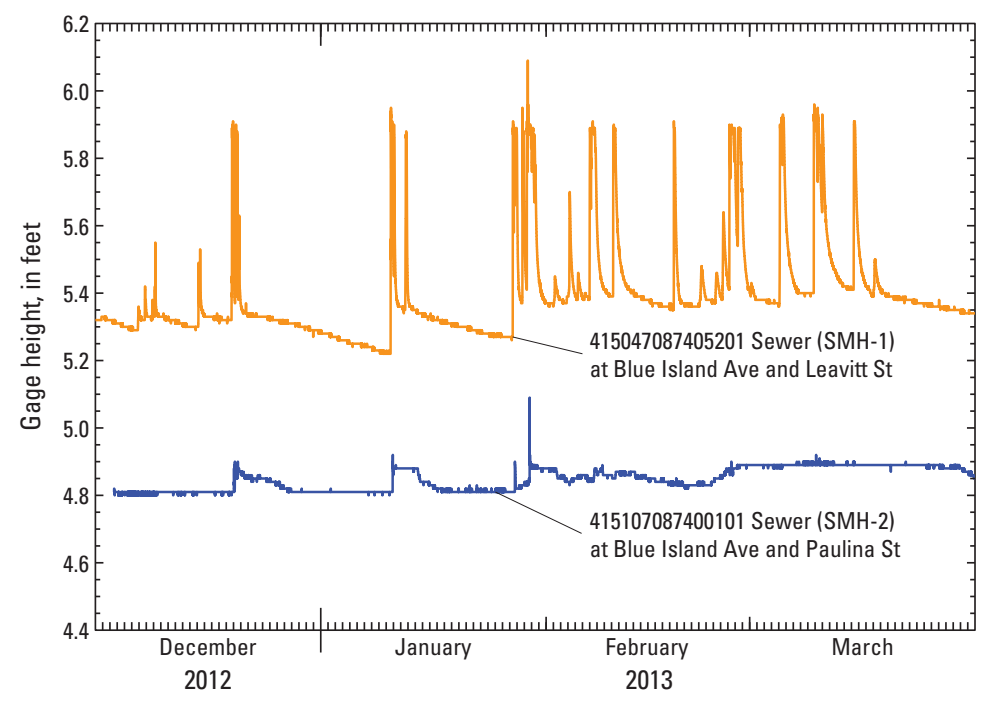

Figure 15 (left). Water-level data from two catch basins (South Paulina Street with permeable pavers and South Leavitt Street without permeable pavers) show the effects that permeable pavers have on stormwater runoff.

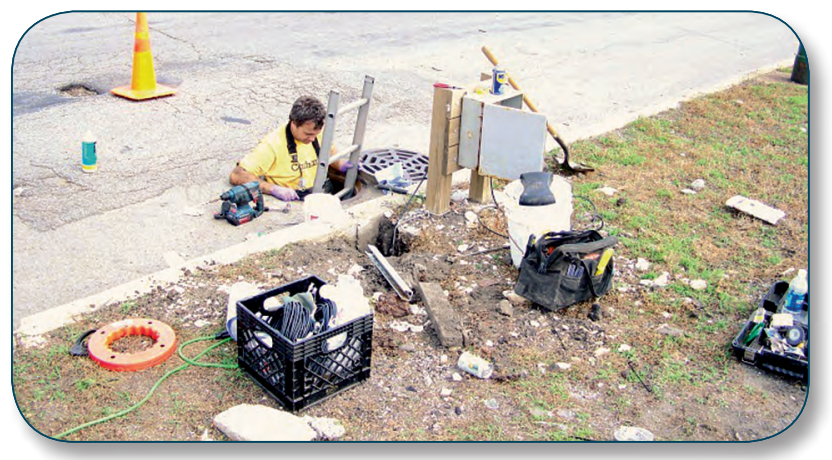

Figure 16. Installing monitoring equipment at West Blue Island Avenue near South Leavitt Street. (Photo by J. Duncker.)
U.S. Geological Survey / Illinois Water Science Center 405 N. Goodwin Ave.

Urbana, IL 61801

217.328.8747 